\title{
Migration and habitat use of the landlocked riverine Atlantic salmon Salmo salar småblank
}

\author{
Jan G. Davidsen · Linda Eikås · Richard D. Hedger • Eva B. Thorstad • \\ Lars Rønning • Aslak D. Sjursen • Ole K. Berg • Gunnbjørn Bremset • \\ Sten Karlsson • Line E. Sundt-Hansen
}

Received: 2 January 2020/Revised: 1 April 2020/Accepted: 3 April 2020/Published online: 18 April 2020

(C) The Author(s) 2020

\begin{abstract}
Småblank" is the only population of Atlantic salmon in Europe living its entire life in the river habitat without performing migrations to the sea or lakes. Home range size and habitat use were compared between an unregulated tributary and hydro-power regulated parts of the main river during 2014-2017. In total, 140 småblank were tagged with radio transmitters and tracked for 4-5 months. Tagged fish tended to stay within small areas: the average $50 \%$ home range was $1123 \mathrm{~m}^{2}$ and the average $95 \%$ home range was $4416 \mathrm{~m}^{2}$. Mean distance between the furthermost positions for individual fish during tracking was $242 \mathrm{~m}$, and the fish did not migrate between different stretches of the river. The small home range and non-migrating behaviour may explain why småblank are divided into several genetically distinct populations with limited gene flow. The results
\end{abstract}

Handling editor: Michael Power

J. G. Davidsen $(\bowtie) \cdot$ L. Eikås · L. Rønning ·

A. D. Sjursen

NTNU University Museum, Norwegian University of

Science and Technology, Trondheim, Norway

e-mail: jan.davidsen@ntnu.no

R. D. Hedger - E. B. Thorstad · G. Bremset .

S. Karlsson - L. E. Sundt-Hansen

NINA, Trondheim, Norway

O. K. Berg

NTNU Department of Biology, Norwegian University of Science and Technology, Trondheim, Norway showed that småblank were far more stationary than what is known for other landlocked salmon populations. Use of moderate or high water velocities' $\left(>50 \mathrm{~s}^{-1}\right)$ areas with coarse river substrates implies a vulnerability to anthropogenic effects such as water diversion, dams and weirs.

Keywords Home range $\cdot$ Movement $\cdot$ Namsblank · Landlocked $\cdot$ Relict salmon

\section{Introduction}

Anadromy, with spawning and rearing in freshwater and feeding migrations to the sea, is the most common life history strategy for Atlantic salmon (Salmo salar Linnaeus, 1758). Non-anadromy occurs either as a reproductive strategy predominately in males that mature as parr in freshwater (Thomaz et al., 1997), or entire populations can be freshwater-resident, with both males and females remaining in freshwater throughout their life cycle (Klemetsen et al., 2003; Hutchings et al., 2019). Many of these freshwaterresident populations are landlocked-unable to perform feeding migrations between freshwater and the sea due to physical barriers such as waterfalls or dams-but some freshwater-resident populations have potential access to the sea (Behnke, 1972). Freshwater-resident populations of Atlantic salmon occur in both northeast North America and Europe (Kazakov, 
1992; Ozerov et al., 2010; Hutchings et al., 2019). Many landlocked populations have migrations between river and downstream lakes, and a large fraction of these populations have declined due to anthropogenic impacts, and some populations have become extinct (Ozerov et al., 2010; Hutchings et al., 2019).

The greatest threats to the persistence of landlocked salmon are found in Europe (Hutchings et al., 2019), including Norway, where the status of landlocked salmon is poor. Historically, there were at least four landlocked populations in Norway, but two were extirpated and a third came close to extirpation due to hydro-power development and acidification. The latter population ("bleke" from the Byglandsfjorden area, southern Norway) is now restored after large-scale stockings from a gene bank facility. The fourth population, called småblank (Berg, 1953), is regarded as having the least secure conservation status of all remaining landlocked populations in terms of extinction risk (Hutchings et al., 2019). Småblank is the only river-resident population in Europe, with no feeding migrations to lakes (Berg, 1984b). A few populations in North America have adapted a similar river-resident strategy (Behnke, 1972). Populations that do not utilize lakes are particularly vulnerable to negative impacts from anthropogenic changes in the river.

Habitat fragmentation and diminished population abundance can reduce genetic diversity and increase extinction risk. This is most likely the case for småblank, which has a lower genetic variation than anadromous Atlantic salmon, and is a unique endemic island population of Atlantic salmon (Bourret et al., 2013; Sandlund et al., 2014). It is in a precarious situation due to a variety of anthropogenic impacts on its restricted habitat area: reduced water discharge, hydro-power dams and weirs causing fragmentation and a change from lotic to lentic conditions, introduced species, and hybridization with anadromous Atlantic salmon after the construction of fishways (Sandlund et al., 2014; Karlsson et al., 2018). In addition, the regulated water flow of the main river contributes to sediment packing of the stony substratum and reduced shelter availability (Sandlund et al., 2014), which is important for growth and abundance of juvenile salmon (Finstad et al., 2007). Thus, maintaining population size, avoiding further habitat fragmentation and reducing negative impacts of river regulation are important for protecting this population.
To improve the conservation status, it might also be necessary to restore suitable habitat in the degraded parts of the watershed.

The habitat use of stream-dwelling salmonids provides vital information on their life history. In contrast to landlocked salmon that migrate into lakes as part of their life cycle, little is known on the movement patterns and habitat use of individuals of river-resident Atlantic salmon populations. However, they differ genetically (Bourret et al., 2013) and in many aspects of their life-history (Sandlund et al., 2014) to anadromous Atlantic salmon, so it is also likely that they may differ in habitat use to anadromous Atlantic salmon. Identifying essential habitat is crucial when evaluating conservation status and planning measures to improve their status, including habitat restoration and identification of potential protection areas. We therefore tagged individual småblank with radio transmitters and tracked their movements over five periods (in the years 2014-2017). The aims of the study were (1) to examine the home range size and length of the river stretch used by individuals in the regulated main river and in a non-regulated tributary, and (2) to describe their habitat use in terms of water velocity and bottom substrate.

\section{Materials and methods}

Study area

The River Namsen (total length $174 \mathrm{~km}$ ) originates from Lake Store Namsvatnet $450 \mathrm{~m}$ above sea level and enters the sea at the inner part of Namsenfjorden, Middle Norway (Fig. 1). The total catchment area is $6300 \mathrm{~km}^{2}$. The landlocked salmon, småblank, is distributed along a 90-km stretch of the upper River Namsen (from 72 to $\approx 160 \mathrm{~km}$ from the river mouth), in addition to several tributaries (Rikstad, 2004). Within the study area, width of the main river varies from 70 to $250 \mathrm{~m}$, whilst width of the tributary varies from 30 to $50 \mathrm{~m}$. This study was performed in two reaches: (a) in the upstream part of the main river, from Snåsamoen to Strompdalen (including Breidfossen and the mouth of River Frøyningselva), and (b) in the major tributary (100 $\mathrm{km}^{2}$ catchment area), River Mellingselva (Fig. 1), hereafter referred to as "main river" and "tributary", respectively. 


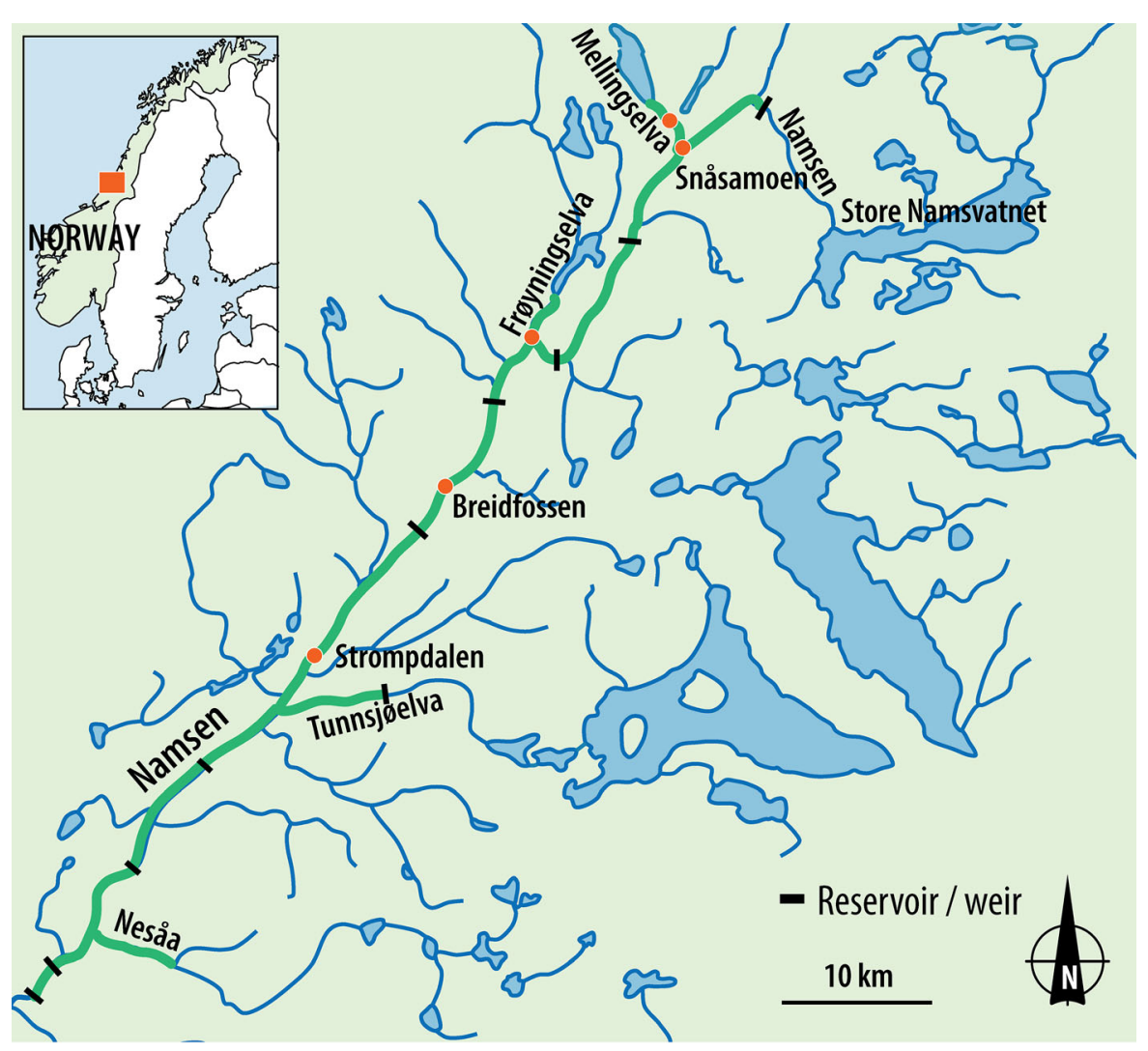

Fig. 1 Location (red dots) of the field sites for radio tagging of småblank (Salmo salar) in the upper River Namsen

The main river is regulated for hydropower production and is characterized as a heavily modified water body. Nine power stations produce in total an average of $1831 \mathrm{GWh}$ per year. Dams and weirs have caused major hydromorphological changes, and in total, more than half of the stretches available for småblank in the main river have changed from lotic to lentic habitat (Sandlund et al., 2014). A major impact is diversion of water from the main river, resulting in reduced catchment areas: for example, the catchment area at Bjørnstadfoss (147 km from the sea; Fig. 1) has been reduced by one-third. As a consequence, both total water discharge and mean water velocities are reduced throughout the year.

Our study site in the main river was not directly affected by dams or weirs, but by reduced water discharge due to the diversion of water. The reach has relatively uniform habitats with long slow-flowing areas combined with shallower riffles (water depths typically $0.5-1.5 \mathrm{~m}$ ). River Mellingselva is an unregulated tributary with no anthropogenic migration obstacles. Compared to the study site in the main river, the habitats are more diverse, with swift rapids, deep pools and waterfalls, and variable substrate categories of sand, gravel, pebble, cobble, boulder and bedrock. The water quality of the study areas in the

Table 1 Environmental variables measured in autumn 2015

\begin{tabular}{lll}
\hline & Snåsamoen & Mellingselva \\
\hline Calcium $(\mathrm{mg} / \mathrm{l})$ & $<5$ & $<5$ \\
Conductivity $(\mu \mathrm{s} / \mathrm{om})$ & 11 & 25 \\
Nitrogen $(\mu \mathrm{g} / \mathrm{l})$ & 70 & 85 \\
Oxygen $(\%)$ & 81 & 80 \\
$\mathrm{pH}$ & 6.8 & 7.0 \\
Phosphorus $(\mu \mathrm{g} / \mathrm{l})$ & $<2$ & $<2$ \\
Temperature $\left({ }^{\circ} \mathrm{C}\right)$ & 12.5 & 13.2 \\
\hline
\end{tabular}

Nitrogen and phosphorus were analysed by Analysesenteret in Trondheim kommune in December 2015. pH, conductivity, oxygen, calcium and temperature were measured in the field on 07.10 .2015 
main river and tributary is characterized by a $\mathrm{pH}$ over 6.0 and low contents of nitrogen and phosphorus (Table 1; nitrogen and phosphorus were analysed by "Analysesenteret Trondheim Kommune" whilst the other parameters were determined in field). Measured values were typical for these lower mountain areas.

To our knowledge, the only other fish species present in the study sites is brown trout Salmo trutta (Linnaeus, 1758). European minnow Phoxinus phoxinus (Linnaeus, 1758) has been recently introduced to the watercourse but is only found as single individuals within the study sites. The construction of fish passages in two hydro-power dams has given anadromous Atlantic salmon access to the lower part of the distribution area for småblank, hence reducing the allopatric distribution of småblank by $10 \mathrm{~km}$ in the main river. However, this has had no effect on our study sites further upstream.

\section{Capture and tagging of fish}

A total of 140 småblank (total length: mean $=169$ $\mathrm{mm}, \mathrm{SD}=24$, range $138-265 \mathrm{~mm}$; body mass ( $n=133$ ), measurements of body mass were missing for seven fish: mean $43 \mathrm{~g}$; $\mathrm{SD}=22$; range 19-136 g) were captured using a backpack electrofishing apparatus (700 or 1400 Volt DC, depending on water conductivity) and tagged with radio transmitters (Advanced Telemetry Systems, ATS, USA, large model: F1440, $2.1 \mathrm{~g}$ in air, estimated battery life 122 days; small model: F1420, $1.3 \mathrm{~g}$ in air, estimated battery life 45 days). The fish were caught between 2014 and 2017 in different locations (Table 2). Individual fish were recognized by the use of different transmitter frequencies within the 142.000 to $142.700 \mathrm{MHz}$ range. Before implanting the transmitters, the fish were anaesthetized in 2-phenoxy-ethanol (EEC No 204-589-7, $0.50 \mathrm{ml}$ per 1 water, each fish kept for 4.0-4.5 min in the bath). During surgery (approximately $3.5 \mathrm{~min}$ per fish), a tube with flowing water was placed in the fish mouth, enabling oxygen uptake by the gills. Total body length and mass were measured and a small part of the adipose fin was sampled for genetic sex determination and 5-7 fish scales were sampled for age reading. To reduce the potential effects of catch and tagging on results and conclusions, tracking data from the first day after release were not included in the analyses. All the fish were caught and released in the same location. Based on tagging area, season and year, the 140 fish were divided into eight groups, and released at six localities (Table 2).

\section{Radio tracking}

The study was conducted from August 2014 to August 2017, covering five tracking periods (Fig. 2). Each tracking period lasted 4-5 months. New fish were tagged for each period due to the restricted battery life of the transmitters. Tracking surveys were conducted every third week, by wading through the river using an ATS model R4500s receiver connected to a fiveelement Yagi antenna. During each survey, individual fish were positioned to the nearest $\pm 1 \mathrm{~m}$. At the position of each fish, water depth was measured and water velocity and substrate were categorized (see Table 3). In situations when it was not possible to get close to the fish, due to floods or the fish being located in deep waters, the GPS-positioned location of the person tracking the fish and the direction and approximate distance to the fish were noted. During these cases, depth, velocity and substrate were not recorded. Each fish position was recorded using a Garmin GPS model 60CSx (accuracy of circa $5 \mathrm{~m}$ ).

The tracking effort was limited by time constraints, and the tracking was therefore restricted to a certain area. In the main river (at Snåsamoen, including the confluence with the tributary Mellingselva), a total river surface area of $101,500 \mathrm{~m}^{2}$ was covered during tracking. In the tributary, an area of $70,000 \mathrm{~m}^{2}$ was covered (Fig. 1).

Determination of age, sex and body condition

The age of the fish was determined from scale analysis (Dahl, 1910; Závorka et al., 2014). Scales from 119 fish were suitable for age determination. For the remaining fish, samples only contained replacement scales that were unsuitable for age analysis.

From the 140 radio-tracked fish, genetic DNA was sampled from 132 adipose fins and analysed for sex and species determination at the Norwegian Institute for Nature Research. The sex for the eight remaining individuals was determined visually in the field during the autumn and hence prior to spawning. For the 132 individuals, the sex was determined from amplifying the male-specific sdY gene in Atlantic salmon using the marker developed by Quéméré et al. (2014), 
Table 2 Overview of the nine groups of tagged småblank

\begin{tabular}{|c|c|c|c|c|c|c|c|c|}
\hline Locality & $\begin{array}{l}\text { Tagging } \\
\text { group }\end{array}$ & $\begin{array}{l}\text { Date } \\
\text { (release) }\end{array}$ & $\begin{array}{l}\text { Number of days } \\
\text { of tracked (d) }\end{array}$ & $\begin{array}{l}\text { Number } \\
\text { of fish } \\
(n)\end{array}$ & $\begin{array}{l}\text { Total body } \\
\text { length }(\mathrm{mm})\end{array}$ & Mass (g) & Age & $\begin{array}{l}\text { Proportion } \\
\text { of females }\end{array}$ \\
\hline Snåsamoen & 1 & 2014-08-26 & 104 & 37 & $165(140-210)$ & $39(23-81)$ & $3.4(3-4)$ & 0.74 \\
\hline Snåsamoen & 2 & 2015-05-04 & 135 & 20 & $163(149-180)$ & $29(19-39)$ & $4.1(2-5)$ & 0.85 \\
\hline $\begin{array}{l}\text { Mellingselva: upper } \\
\text { part }\end{array}$ & 3 & 2015-08-21 & 144 & 25 & $162(140-206)$ & 42 (25-93) & $3.2(2-4)$ & 0.52 \\
\hline $\begin{array}{l}\text { Mellingselva: lower } \\
\text { part }\end{array}$ & 4 & $2015-08-25$ & 140 & 11 & $153(138-167)$ & $34(23-46)$ & $3.6(3-4)$ & 0.45 \\
\hline $\begin{array}{l}\text { River Frøyningselva } \\
\text { outlet }\end{array}$ & 5 & $2015-08-20$ & 116 & 10 & $158(143-188)$ & $34(24-56)$ & $3.2(2-5)$ & 0.89 \\
\hline Breidfossen & 6 & 2016-09-21 & 84 & 8 & $181(160-206)$ & $51(35-77)$ & $3.5(3-4)$ & 0.25 \\
\hline Breidfossen & 7 & $2017-05-15$ & 80 & 11 & $176(141-253)$ & $47(20-115)$ & $3.8(3-6)$ & 0.29 \\
\hline Strompdalen & 8 & 2016-08-09 & 126 & 18 & $199(150-265)$ & $70(29-136)$ & $3.9(2-7)$ & 0.61 \\
\hline
\end{tabular}

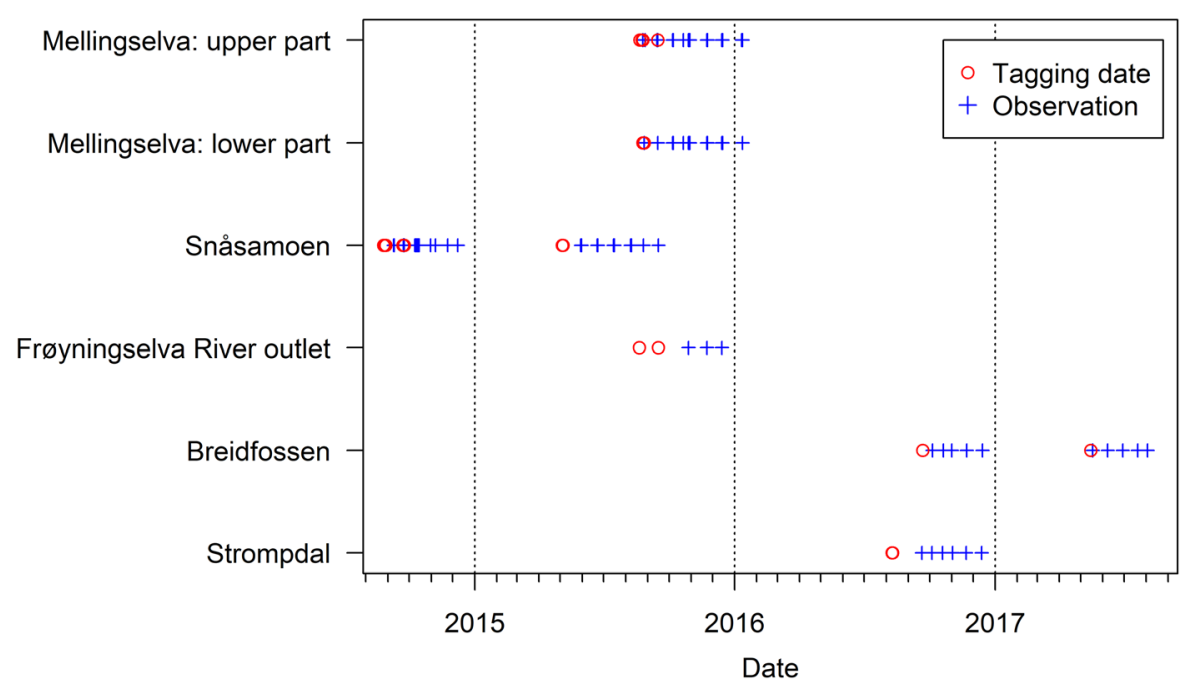

Fig. 2 Overview of periods of tagging and radio tracking of småblank (Salmo salar) in the upper River Namsen

Table 3 Categorization system for defining water velocity and substrate at the småblank locations

\begin{tabular}{lll}
\hline Category & Water velocity & Particle size \\
\hline 1 & Stagnant water: $0-0.2 \mathrm{~ms}^{-1}$ & Fine substrate: $<2 \mathrm{~cm}$ \\
2 & Slow current: $0.2-0.5 \mathrm{~ms}^{-1}$ & Gravel/pebble: $2-16 \mathrm{~cm}$ \\
3 & Moderate current: $0.5-1 \mathrm{~ms}^{-1}$ & Cobble: $16-35 \mathrm{~cm}$ \\
4 & Strong current: $>1 \mathrm{~ms}^{-1}$ & Boulder: $>35 \mathrm{~cm}$ \\
5 & Cascade (pronounce falling gradient) & Bedrock \\
\hline
\end{tabular}


together with genetic markers for differentiating Atlantic salmon and brown trout using the PCR assay developed by Karlsson et al. (2013). Because the sdY gene is only amplified in males, absence of an amplification was intepreted as a female, but only when the genetic markers to differentiate between species amplified well in the same PCR muliplex. DNA was extracted from fin-clips preserved in ethanol using the DNEASY tissue kit (QIAGEN). Of the 140 tagged fish, there were 87 females and 53 males. All of the tagged fish were salmon (småblank) and none were hybrids between salmon and trout. Fulton's body condition factor (Fulton, 1904), based on measurements of body mass and total length, was calculated for the 133 fish for which mass was measured.

\section{Data analyses}

The characteristics of tagged fish were first summarized using bivariate statistics. First, the relationship between body length and age was examined using Pearson's correlation and the relationship between body length and sex using a Student's $t$ test. Next, the potential differences in body length, body mass and condition factor between fished tagged in the main river and those tagged in the unregulated tributary were examined using Student's $t$ tests.

For fish that were unreachable by wading, bankside measurements of locations were used, which were repositioned in the GIS software Map 10.2 (desktop.arcgis.com/en/arcmap/) using field notes with estimates of the distance to the fish. Fish locations measured both within the river and from bankside measurements were used for home range estimation.

Home ranges based on GPS positions were estimated for each småblank when there were at least five observations using the following procedure: (1) A $50 \%$ home range polygon (excluding $50 \%$ of the positions furthest away from the home range centroid) was calculated for each småblank using the $\mathrm{R}$ function $m c p$ () from the adehabitatHR library. A 50\% limit prevented the calculated home ranges being unduly influenced by occasional long-distance movements. For comparison, 95\% home ranges were also calculated. (2) The home range polygon for each småblank was further refined to exclude bankside areas by only retaining the intersection between the calculated home range polygon and the river channel using the $R$ function gIntersection() from the rgeos library. Spatial and temporal differences in $50 \%$ home ranges were tested using Mann-Whitney $U$ test. Spatial differences were analysed by comparing home ranges in the main river with those in the tributary, using the home ranges estimated from observations in both parts of the river in the autumn. Temporal differences were analysed by comparing home ranges in the autumn with those in the spring, using home range data available from both seasons at Breidfossen and Snåsamoen in the main river.

Travel distances between consecutive locations for småblank individuals were estimated as follows: (1) For consecutive locations that did not have a boundary (river bank) between them, a simple Euclidean distance was used. (2) For consecutive locations separated by an intermediate boundary, a minimum within-river distance between the locations was estimated using the R-function shortestPath() from the gdistance library.

The effect of småblank characteristics on home range and maximum length of the river stretch used (defined as the maximum distance between two consecutive observations) was examined using linear regression. Both home range and maximum length of the river stretch used were log transformed to ensure a normal distribution of residuals. Length, body mass, condition factor (K), age (in years), sex and the release locality (watercourse stretch) were considered as potential predictors. Generalized variance inflation factors (GVIFs) were examined to explore potential correlation amongst predictors using the R-function $v i f()$ from the car library, following the method outlined by Zuur et al. (2009). High GVIFs were found for body length and mass when they were included in the same model, and body mass, which had the highest GVIF, was therefore excluded (reducing GVIFs to $<1.6$ for body length, condition factor and age, sex and release locality). Initial models were therefore run with body length, condition factor, age, sex, and release locality, and models were simplified using a stepwise approach.

The datasets generated and analysed during the current study are available upon request in the NTNU University Museum repository NaTron, https://natron. vm.ntnu.no/dataCollection/. 


\section{Results}

Body length and body condition

Body length and age were positively correlated (Pearson's correlation, $\quad t=7.60, \quad P<0.001$, $n=119)$. There was no difference in body length between males $($ mean $=164 \mathrm{~mm}$, S.D. $=25$, range $138-165 \mathrm{~mm})$ and females $($ mean $=170 \mathrm{~mm}$, S.D. $=20$, range $140-231 \mathrm{~mm}$ ) (Student's $t$ test, $t=1.29, P=0.20, n=132$ ). In the autumn, småblank tagged in the regulated main river had greater body length and body mass (mean length $=176 \mathrm{~mm}$, mean mass $=49.2 \mathrm{~g}$ ) than those tagged in the unregulated tributary (mean length $=159 \mathrm{~mm}$, mean mass $=39.6$ g) (Student's $t$ test, $\mathrm{t}=3.86, P<0.001$ (body length), $t=92.6, P=0.019$ (body mass), $n=95$ ). However, fish tagged in the regulated main river had lower condition factor (mean $=0.83$, range $0.73-0.95$ ) than those tagged in the unregulated tributary (mean = 0.95 , range 0.78-1.14) (Student's $t$ test, $t=-7.27$ $P<0.001, n=95)$. No comparison was made for the spring, because fish were then only tagged in the main river.

\section{Home range}

The home range size could be estimated for 77 småblank. A median of eight observation locations (S.D. = 4.4, range 5-17) was available for analysis from these fish. The fish stayed within relatively small home ranges, with an average $50 \%$ home range area of $1123 \mathrm{~m}^{2}$ (S.D. $=2794 \mathrm{~m}^{2}$, range $1-18644 \mathrm{~m}^{2}$ ), and an average $95 \%$ home range area of $4416 \mathrm{~m}^{2}$ (S.D. = $7337 \mathrm{~m}^{2}$, range 3-44 $408 \mathrm{~m}^{2}$ ) (Fig. 3). There was large variation in home range size amongst the fish (Fig. 3). Home ranges were larger for småblank residing in the upstream part of the study area (Snåsamoen in the main river and the tributary River Mellingselva) than in the downstream area (Strompdalen and Breidfossen) (Table 4). The 50\% home range size increased with fish age (Table 4). There was no relationship between $50 \%$ home range size and fish condition, body length or sex, which were excluded from the final model through stepwise selection. Despite large differences in median values, the $50 \%$ home range size did not differ between the main river (median $=47 \mathrm{~m}^{2}, n=39$ ) and the tributary (median $=171 \mathrm{~m}^{2}, n=24$ ) for fish tracked in the autumn
(Mann-Whitney $U$ test, $U=365.5, P=0.15$ ). At Breidfossen and Snåsamoen in the main river, småblank were tracked both during autumn and spring. In both localities, 50\% home range sizes did not differ between the spring and the autumn (MannWhitney $U$ test; Breidfossen: $U=8, \quad P=0.50$; Snåsamoen: $U=72, P=0.17)$.

Length of river stretch used

Twelve of the 140 released småblank were only detected on one occasion each, so it was not possible to determine the length of the river stretch used for these individuals. Of the remaining individuals, the median maximum length of the river stretch used (estimated as the longest distance covered between consecutive tracked locations of each individual) was $242 \mathrm{~m}$ (range $0-2080 \mathrm{~m} ; n=128$ ). The median maximum length of the river stretch used was positively correlated to body length (Table 5), but not to age or condition factor. The maximum length was also greater for males than for females. It was also dependent on locality, with småblank in the localities further upstream (Snåsamoen and Mellingselva) and Breidfossen tending to move over longer stretches (Fig. 4, Table 5).

\section{Habitat use}

Småblank were most commonly found in areas with coarse (gravel/pebble to boulder) substrate $(90 \%)$, with moderate to strong currents $(79 \%)$, and at water depths shallower than $60 \mathrm{~cm}(82 \%)$ (Fig. 5, Table 3). They were, however, observed across a range of habitats including areas with fine substrate or bedrock $(10 \%)$, and in either stagnant or slow waters $(16 \%)$ or cascades $(5 \%)$. Småblank were also observed in waters deeper than $60 \mathrm{~cm}$, and all småblank in the main river at Strompdalen were found in waters deeper than $100 \mathrm{~cm}$. The substrate used differed between the tributary and the main river. At Snåsamoen, småblank were mainly found in areas with coarse cobble/boulder substrates (particle size 16-35 cm), whilst småblank in the other parts of the study area were also found in habitats with finer gravel/pebble substrates $(2-15 \mathrm{~cm})$. 


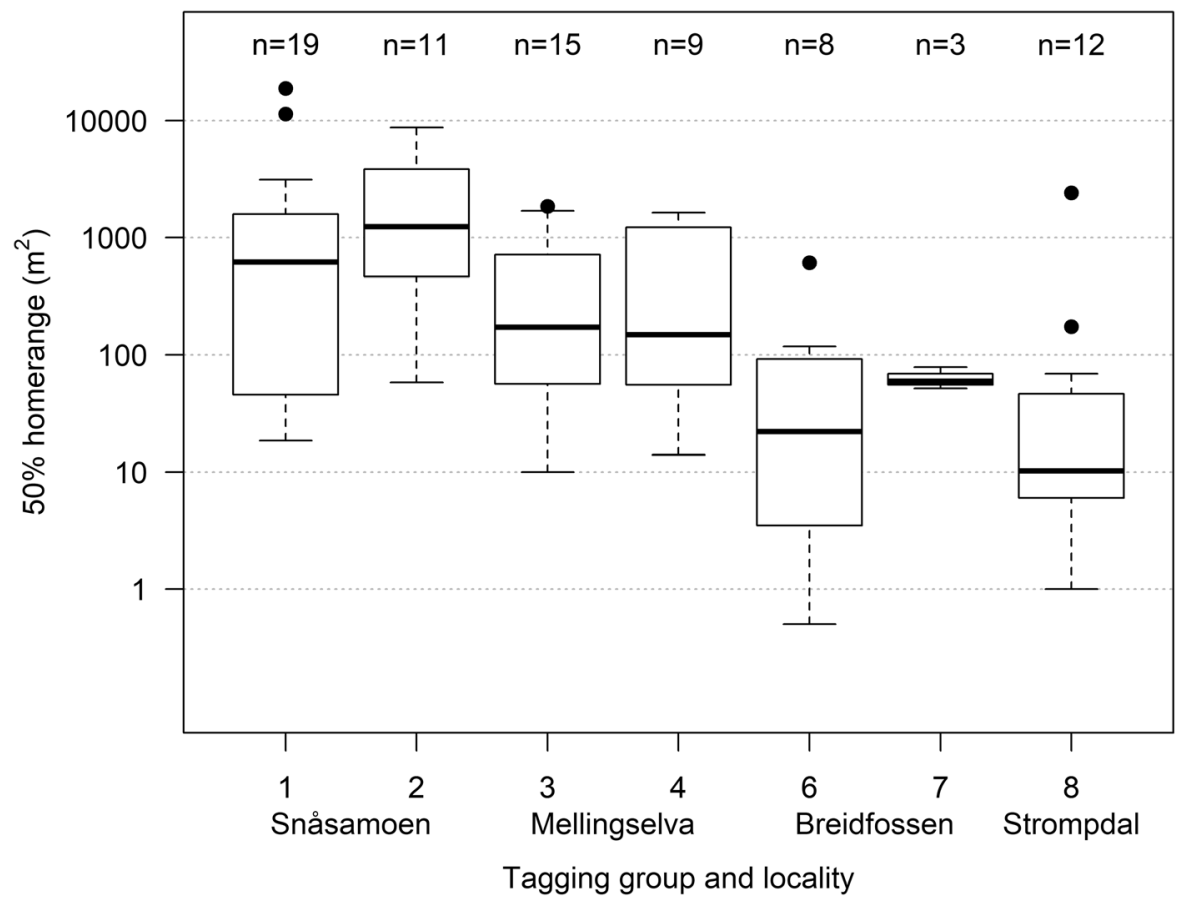

Fig. 3 Home range estimates for radio tagged småblank (Salmo salar) in the upper River Namsen (50\% home range size). Home ranges could not be estimated for tagging group 5 due to a low sample size of observed positions

Table 4 Retained coefficients of stepwise linear regression model of effect of body length, condition factor, age, sex and release locality on småblank $50 \%$ home range size

\begin{tabular}{lrrrr}
\hline & Estimate & SE & $t$ value & $\operatorname{Pr}(>|\mathrm{t}|)$ \\
\hline (Intercept) & -1.334 & 1.182 & -1.128 & 0.263 \\
Age & 1.138 & 0.289 & 3.936 & 0.001 \\
Locality: Breidfossen & 0.522 & 0.757 & 0.690 & 0.493 \\
Locality: Snåsamoen & 3.058 & 0.644 & 4.746 & 2.817 \\
Locality: Mellingselva, lower part & 2.250 & 0.799 & 3.98 & 0.006 \\
Locality: Mellingselva, upper part & 2.938 & 0.738 & $<0.001$ \\
\hline
\end{tabular}

Table 5 Retained coefficients of stepwise linear regression model of effect of body length, condition factor, age, sex and release locality on maximum length of the river stretch used

\begin{tabular}{lrrrr}
\hline & Estimate & Std. Error & $\mathrm{t}$ value & $\operatorname{Pr}(>|\mathrm{t}|)$ \\
\hline (Intercept) & -0.068 & 1.259 & -0.054 & 0.957 \\
Body length & 0.018 & 0.006 & 2.876 & 0.005 \\
Sex: Male & 0.647 & 0.242 & 2.670 & 0.009 \\
Locality: Breidfossen & 1.203 & 0.441 & 2.728 & 0.008 \\
Locality: River Frøyningsleva outlet & 0.339 & 0.537 & -0.631 & 0.529 \\
Locality: Snåsamoen & 2.389 & 0.397 & 6.011 & $<0.001$ \\
Locality: River Mellingselva: lower part & 2.500 & 0.529 & 4.722 & $<0.001$ \\
Locality: River Mellingselva: upper part & 1.623 & 0.437 & 3.717 & $<0.001$ \\
\hline
\end{tabular}




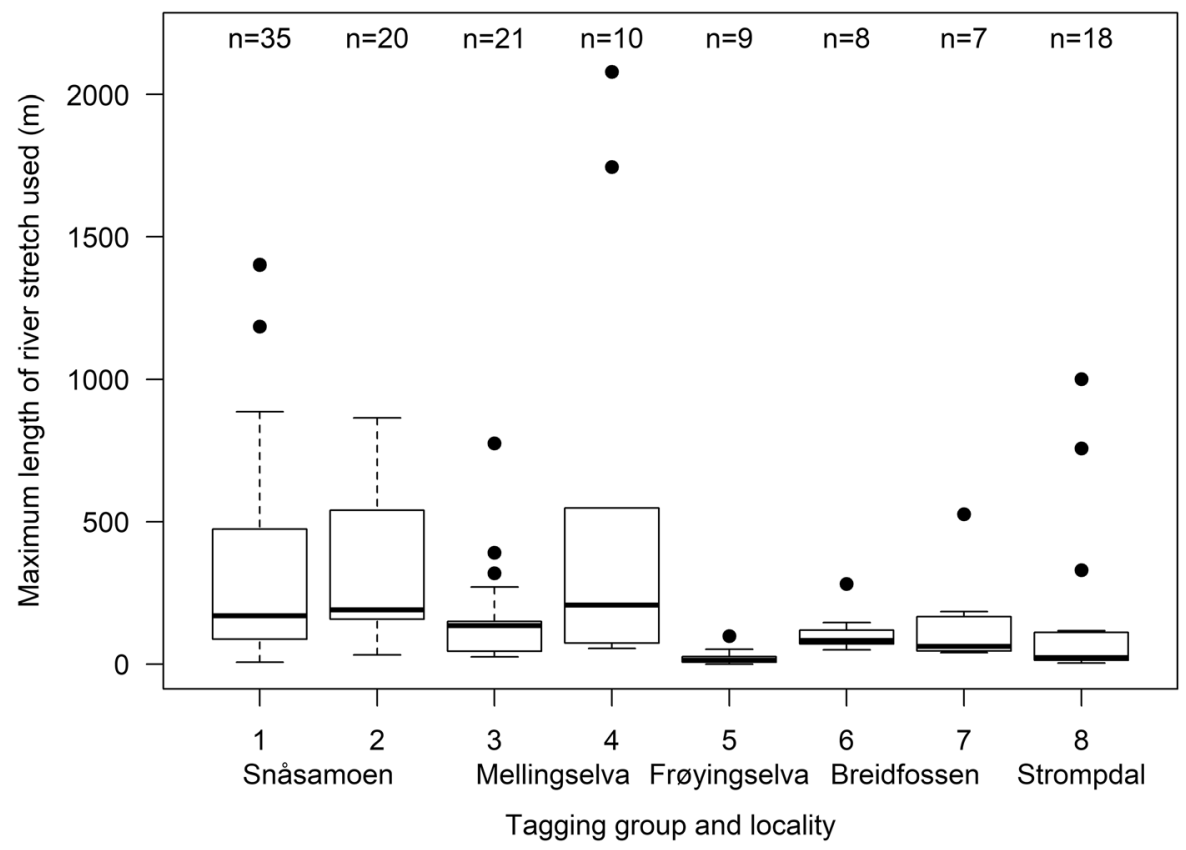

Fig. 4 Maximum length of river stretch used by radio tagged småblank (Salmo salar) in the upper River Namsen
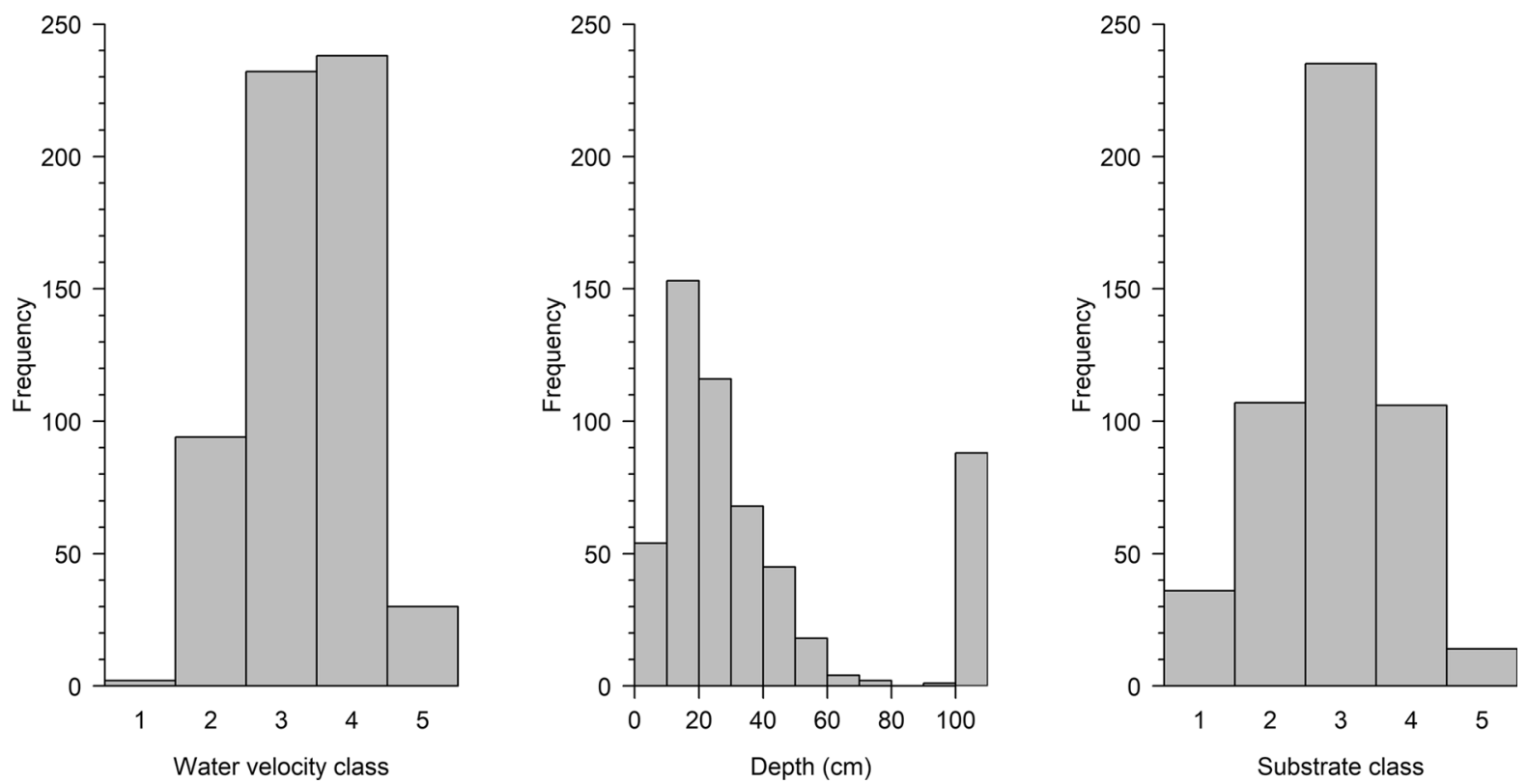

Fig. 5 Habitat distribution (water velocity, depth and substrate class) of locations where radio tagged småblank were observed

\section{Discussion}

The småblank did not display similar migratory behaviour as observed in most other landlocked populations of Atlantic salmon. Compared to the migrations between rivers and lakes in landlocked salmon in the watercourses of Ladoga, Onega, Saimaa, Vänern and Otra (Berg, 1985; Kazakov, 1992; Anon, 2011), the småblank were relatively stationary, with small home ranges (spending $50 \%$ of their time within 
an area of only $1123 \mathrm{~m}^{2}$ and $95 \%$ of the time within an area of $4416 \mathrm{~m}^{2}$ ). They were also confined to short river stretches, as no fish moved over a longer river stretch than about $2 \mathrm{~km}$, and half the fish did not use a river stretch longer than about $240 \mathrm{~m}$. This shows that the tagged fish were stationary within the same river section during the entire tracking period. The short movements of småblank concur with the results in a previous study (1954-1958) from the same area, based on Carlin tags and recaptures (Berg, 1984b). Of approximately one thousand tagged fish, all recaptures were reported from the same area as the fish were tagged, except one individual recaptured $24 \mathrm{~km}$ downstream, and ten individuals about $10 \mathrm{~km}$ downstream (Berg, 1984a). Major migrations are usually associated with reproduction, seasonal preferences for different habitats (e.g. for overwintering), or as an effect of increased body size. In salmonids, smoltification stimulates downstream migration in both anadromous and non-anadromous salmon (e.g. Kendall et al., 2015). In the current study, småblank were tracked during spring, summer and autumn without any indication of seasonal or other kinds of migrations. For anadromous Atlantic salmon, spawning migrations take place during the summer and autumn and the smolt migration in the spring, so these kind of migrations should have been observed if they occurred.

Småblank residing in the upper part of the study area (Snåsamoen and Mellingselva) had larger home ranges than those residing in the downstream part (Breidfossen and Strompdalen). There might be several reasons for this difference: (1) Access to food and/ or shelter may differ between the two areas, and småblank may adapt their home range accordingly. (2) The number of competitors may differ between the two areas, and the home range may be adapted to the competitive pressure. Displacement of individual salmonids by more competitive conspecifics in territorial communities of juvenile fish is well-known, and in such cases, the sub-dominant individuals may need to explore larger areas without being territorial (Grant \& Kramer, 1990; Titus 1990; Grant, 1997). Experimental studies have shown that the territory size of juvenile salmonids decreases with increasing density, and increases with decreasing levels of accessible food (Kalleberg, 1958). Due to the low density of småblank in most of the studied areas, it is less likely that the populations were regulated by a high level of territoriality. However, access to food and shelter and the level of competition may still have a major impact on the spatial distribution and habitat use of småblank, and these factors may in combination influence their home range size.

In general, home range increased with fish age, and length of the river stretch used increased with fish body length. Smaller individuals of småblank share several characteristics with juvenile anadromous salmon, which in general need access to suitable shelter (Heggenes et al., 1999; Bremset \& Heggenes, 2001; Finstad et al., 2007) to reduce the predation risk (Metcalfe et al.,, 1987; Vehanen, 2003). In general, larger småblank may be less vulnerable to cannibalism and predation. Hence, they may be less dependent on accessible shelter and may move over larger areas than smaller individuals.

The difference in substrate use between Snåsamoen, where småblank mainly used coarse cobble/ boulder substrates, and the other study areas, where fish more often were found in areas with finer gravel/ pebble substrates, is probably due to differences in the bottom substrate between these localities and not to site-specific preferences. Both substrate categories provide suitable shelters for juvenile salmonids (Heggenes et al., 1999; Bremset \& Heggenes, 2001; Orpwood et al., 2003), and an earlier study has indicated that this is the case for similar-sized småblank as in the current study (Norum, 2010).

Småblank mainly utilized areas with water depths shallower than $60 \mathrm{~cm}$ and moderate or high water velocities $\left(>50 \mathrm{~s}^{-1}\right)$. These water velocities make it possible for the fish to keep position near the river bottom and at the same time feed on drifting invertebrates. Access to drifting invertebrates depends on water velocities, since the rate of drifting material within a given river section is proportional to the speed of flow (Metcalfe, 1986; Nislow et al., 1998). The water velocities utilized by småblank in the present study (generally $>50 \mathrm{~cm} \mathrm{~s}^{-1}$ ) were faster than what is normally preferred by juvenile anadromous salmonids. Degraaf \& Bain (1986) and Morantz et al. (1987) found that $0+$ Atlantic salmon prefer areas with water velocities slower than $20 \mathrm{~cm} \mathrm{~s}^{-1}$, whilst Heggenes et al. (1995) observed that older juveniles preferred water velocities up to $25 \mathrm{~cm} \mathrm{~s}^{-1}$. As småblank have a larger maximum size than juvenile salmon as well as significant larger pectoral fins (Berg, 1984a), the maximum swimming capacity of 
småblank is quite high. Consequently, large småblank are able to hold position in high-velocity areas of rivers that are unsuitable for smaller individuals.

\section{Conclusion}

In conclusion, this study shows that småblank, in contrast to other salmon populations, have relatively restricted home ranges and that they do not migrate between different parts of the river. These findings may partly explain why småblank is divided into several genetically distinct populations (Ståhl, 1987; Vuorinen \& Berg, 1989; Sandlund et al., 2014). Further, the current study supports previous observations showing that småblank prefer fast-running waters, and are able to use river areas unsuited for smaller individuals such as juveniles of salmon and trout. A special adaptation to such areas with coarse river substrates implies a vulnerability to anthropogenic activities such as water diversion, dams and weirs. As a consequence of being a small population with special adaptations, further habitat degradation might inflict a decline in the småblank population and subpopulations.

Ackowledgments Open Access funding provided by NTNU Norwegian University of Science and Technology (incl St. Olavs Hospital - Trondheim University Hospital). We would like to thank Jarle Fløan, Reidar Smalås and Sissel Grongstad at Namsskogan Fjellstyre, Jon Museth and John Gunnar Dokk from NINA and Stein-Hugo Hemmingsen and students at NTNU for assistance during the fieldwork. The study was funded by Nord-Trøndelag Elektrisitetsverk (NTE). The experimental procedures were approved by the Norwegian National Animal Research Authority (Permission Number 2014/156779).

Open Access This article is licensed under a Creative Commons Attribution 4.0 International License, which permits use, sharing, adaptation, distribution and reproduction in any medium or format, as long as you give appropriate credit to the original author(s) and the source, provide a link to the Creative Commons licence, and indicate if changes were made. The images or other third party material in this article are included in the article's Creative Commons licence, unless indicated otherwise in a credit line to the material. If material is not included in the article's Creative Commons licence and your intended use is not permitted by statutory regulation or exceeds the permitted use, you will need to obtain permission directly from the copyright holder. To view a copy of this licence, visit http://creativecommons.org/licenses/by/4.0/.

\section{References}

Anon., 2011. Status of Norwegian salmon populations in 2011 Norwegian Scientific Advisory Committee for Atlantic Salmon Management Report. vol 3, Trondheim, 285.

Behnke, R. J., 1972. The systematics of salmonid fishes of recently Glaciated lakes. Journal of the Fisheries Research Board of Canada 29: 639-671.

Berg, M., 1953. A relict Salmon, Salmo salar L., called "Småblank" from the River Namsen, North-Trøndelag. Acta Borelia, A. Scientia 6: 19.

Berg, O. K., 1984a. Comparison between the distributions of land-locked Atlantic salmon (Salmo salar L.) and threespined stickleback (Gasterosteus aculeatus L.) in the river Namsen, Norway. Fauna norvegica Ser A 5: 37-41.

Berg, O. K., 1984b. Utvandring av relikt laks, småblank, fra Namsen, Nord-Trøndelag fylke Direktoratet for vilt og ferskvannsfisk report. Zoologisk Institutt, Trondheim.

Berg, O. K., 1985. The formation of non-anadromous populations of Atlantic salmon, Salmon salar L., in Europe. Journal of Fish Biology 27: 805-815.

Bourret, V., M. P. Kent, C. R. Primmer, A. Vasemägi, S. Karlsson, K. Hindar, P. McGinnity, E. Verspoor, L. Bernatchez \& S. Lien, 2013. SNP-array reveals genome-wide patterns of geographical and potential adaptive divergence across the natural range of Atlantic salmon (Salmo salar). Molecular Ecology Notes 22: 532-551.

Bremset, G. \& J. Heggenes, 2001. Competitive interactions in young Atlantic salmon (Salmo salar L) and brown trout (Salmo trutta L) in lotic environments. Nordic Journal of Freshwater Research 75: 127-142.

Dahl, K., 1910. Alder og vekst hos laks belyst ved studier av deres skjæl. Centraltrykkeriet, Kristiania.

Degraaf, D. \& L. H. Bain, 1986. Habitat use by and preferences of juvenile Atlantic salmon in two Newfoundland rivers. Transactions of the American Fisheries Society 115: 671-681.

Finstad, A., S. Einum, T. Forseth \& O. Ugedal, 2007. Shelter availability affects behaviour, size-dependent and mean growth of juvenile Atlantic salmon. Freshwater Biology 52: $1710-1718$.

Fulton, T. W., 1904. The rate of growth of fishes. Fisheries Board of Scotland Annual Report 22: 141-241.

Grant, J. W. A., 1997. Territoriality. In Godin, J. G. J. (ed), In Behavioural Ecology of Teleost Fishes. Oxford University Press, New York: 81-103.

Grant, J. W. A. \& D. L. Kramer, 1990. Territory size as a predictor of the upper limit to population density of juvenile salmonids in streams. Canadian Journal of Fisheries and Aquatic Sciences 47: 1724-1737.

Heggenes, J., J. L. Baglinière \& R. A. Cunjak, 1995. Synthetic note on spatial niche selection and competition in young Atlantic salmon (Salmo salar) and brown trout (Salmo trutta) in lotic environments. Bulletin français de la pêche et de la pisciculture 337(338/339): 231-239.

Heggenes, J., J. L. Baglinière \& R. A. Cunjak, 1999. Spatial niche variability for young Atlantic salmon (Salmo salar) and brown trout ( $S$. trutta) in heterogeneous streams. Ecology of Freshwater Fish 8: 1-21. 
Hutchings, J. A., W. R. Ardren, B. T. Barlaup, E. Bergman, K. D. Clarke, L. A. Greenberg, C. Lake, J. Piironen, P. Sirois, L. E. Sundt-Hansen \& D. J. Fraser, 2019. Life-history variability and conservation status of landlocked Atlantic salmon: an overview. Canadian Journal of Fisheries and Aquatic Sciences 76: 1697-1708.

Kalleberg, H., 1958. Observations in a stream tank of territoriality and competition in juvenile salmon and trout (Salmo salar L. and S. trutta L.). Reports of the Institute of Freshwater Research, Drottningholm 39: 55-98.

Karlsson, S., M. Hagen, L. Eriksen, K. Hindar, A. J. Jensen, C. Garcia de Leaniz, D. Cotter, G. Gudbergsson, K. Kahilainen \& S. Gudjonsson, 2013. A genetic marker for the maternal identification of Atlantic salmon $\mathrm{x}$ brown trout hybrids. Conservation Genetics Resources 5: 47-49.

Karlsson, S., T. G. Heggberget, O. K. Berg \& L. E. SundtHansen, 2018. Hybridisering mellom småblank og anadrom laks i Øvre Namsen NINA Rapport. Norwegian Institute for Nature Research, Trondheim: 20.

Kazakov, R. V., 1992. Distribution of Atlantic Salmon, Salmo salar L., in freshwater bodies in Europe. Aquaculture Research 23: 461-475.

Kendall, N. W., J. R. McMillan, M. R. Sloat, T. W. Buehrens, T. P. Quinn, G. R. Pess, K. V. Kuzishchin, M. M. McClure \& R. V. Zabel, 2015. Anadromy and residency in steelhead and rainbow trout (Oncorhynchus mykiss): a review of the processes and patterns. Canadian Journal of Fisheries and Aquatic Sciences 72: 319-342.

Klemetsen, A., P. A. Amundsen, J. Dempson, B. Jonsson, N. Jonsson, M. O'connell \& E. Mortensen, 2003. Atlantic salmon Salmo salar L., brown trout Salmo trutta L. and Arctic charr Salvelinus alpinus (L.): a review of aspects of their life histories. Ecology of Freshwater Fish 12: 1-40.

Metcalfe, N. B., 1986. Intraspecific variation in competitive ability and food intak in salmonids: consequences for energy budgets and growth rates. Journal of Fish Biology 28: 525-531.

Metcalfe, N. B., F. A. Huntingford \& J. E. Thorpe, 1987. The influence of predation risk on the feeding motivation and foraging strategy of juvenile Atlantic salmon. Animal Behaviour 35: 901-911.

Morantz, D., R. Sweeney, C. Shirvell \& D. Longard, 1987. Selection of microhabitat in summer by juvenile Atlantic salmon (Salmo salar). Canadian Journal of Fisheries and Aquatic Sciences 44: 120-129.

Nislow, K. H., C. Folt \& M. Seandel, 1998. Food and foraging behaviour in relation to microhabitat use and survival of age-0 Atlantic salmon. Canadian Journal of Fisheries and Aquatic Sciences 55: 116-127.

Norum, I. C. J., 2010. Habitatkrav og habitattilgjengelighet for småblank (Salmo salar), relikt laks i øvre Namsen. Master of Science in freshwater ecology, Department of biologi, NTNU, Trondheim.

Orpwood, J. E., S. W. Griffiths \& J. D. Armstrong, 2003. Effects of body size on sympatric shelter use in overwintering juvenile salmonids. Journal of Fish Biology 63: 166-173.

Ozerov, M. Y., J. Lumme, A. J. Veselov \& C. R. Primmer, 2010. Genetic structure of freshwater Atlantic salmon (Salmo salar L.) populations from the lakes Onega and Ladoga of northwest Russia and implications for conservation. Conservation Genetics 11: 1711-1724.

Quéméré, E., C. Perrier, A.-L. Besnard, G. Evanno, J. L. Baglinière, Y. Guiguen \& S. Launey, 2014. An improved PCR-based method for faster sex determination in brown trout (Salmo trutta) and Atlantic salmon (Salmo salar). Conservation Genetics Resources 6: 825-827.

Rikstad, A., 2004. Overvåking av Namsblank, dverglaksen fra Øvre Namsen Fylkesmannen i Nord-Trøndelag Report. 15.

Sandlund, O. T., S. Karlsson, E. B. Thorstad, O. K. Berg, M. P. Kent, I. C. J. Norum \& K. Hindar, 2014. Spatial and temporal genetic structure of a river-resident Atlantic salmon (Salmo salar) after millennia of isolation. Ecology and Evolution 4: 1538-1554.

Ståhl, G., 1987. Genetic population structure of Atlantic salmon. In Ryman, N. \& F. Utter (eds), Population genetics and fishery management. University of Washington Press, Seattle, WA: 121-140.

Thomaz, D., E. Beall \& T. Burke, 1997. Alternative reproductive tactics in Atlantic salmon: factors affecting mature parr success. Proceedings of the Royal Society B: Biological Sciences 264: 219-226.

Titus, R. G., 1990. Territorial behavior and its role in population regulation of young brown trout (Salmo trutta): new perspectives. Annales Zoologici Fennici 27: 119-130.

Vehanen, T., 2003. Adaptive flexibility in the behaviour of juvenile Atlantic salmon: short-term responses to food availability and threat from predation. Journal of Fish Biology 63: 1034-1045.

Vuorinen, J. \& O. K. Berg, 1989. Genetic divergence of anadromous and nonanadromous Atlantic salmon (Salmo salar) in the River Namsen, Norway. Canadian Journal of Fisheries and Aquatic Sciences 46: 406-409.

Závorka, L., O. Slavík \& P. Horký, 2014. Validation of scalereading estimates of age and growth in a brown trout Salmo trutta population. Biologia 69: 691-695.

Zuur, A. F., E. N. Leno, N. J. Walker, A. A. Saveliev \& G. M. Smith, 2009. Mixed Effects Models and Extensions in Ecology with R. Springer, New York.

Publisher's Note Springer Nature remains neutral with regard to jurisdictional claims in published maps and institutional affiliations. 